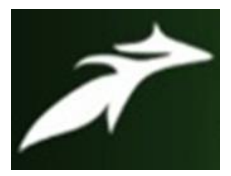

Arjun Shukla et al, International Journal of Advances in Agricultural Science and Technology,

Vol.8 Issue.8, August-2021, pg. 201-209

ISSN: 2348-1358

Impact Factor: 6.057

NAAS Rating: 3.77

\title{
Comparative Studies of Tomato and Cherry Tomatoes Different Varieties under Poly House Condition
}

\author{
*Arjun Shukla ${ }^{1}$; Prof (Dr.) V. M Prasad ${ }^{2}$; Dr. Vijay Bahadur ${ }^{3}$; Samir E. Topno ${ }^{4}$ \\ ${ }^{1}$ PG Student, ${ }^{2}$ Professor, ${ }^{3}$ Associate Professor, ${ }^{4}$ Assistant Professor \\ Department of Horticulture, Naini Agricultural Institute, Sam Higginbottom University of Agriculture, Technology \\ and Sciences, Prayagraj 211007 (UP), India \\ *Email Id- arjun97shukla@gmail.com \\ DOI: 10.47856/ijaast.2021.v08i8.022
}

\begin{abstract}
Research was carried out at Vegetable Research Farm, Department of horticulture, SHUATS, Prayagraj (U.P.) during winter season of 2020 - 2021, to evaluate different varieties of poly house condition traits of 7 Hybrids, with three replications in Randomized Block Design (RBD). Analysis of variance in the present investigation indicated that the genotypes evaluated differed significantly among all the treatment for all Thirteen traits. The hybrids Arka rakshak $(887.01 \mathrm{~kg}$ ) yield/hac and Total cost of cultivation (INR ha') 72,250.00. Cost Benefit Ratio of different varieties of tomato, Variable cost and total cost of cultivation of different varieties, Economics of cherry tomato and tomatos, Yield per hectare \& plant height $(\mathrm{cm})$.
\end{abstract}

Keywords: Tomato, Yield and Quality

\section{INTRODUCTION}

The tomato covers about 3.55 lakh hectares area (2007) in India with a production of 54.41 lakh tonnes and productivity of 15.32 tonnes/ ha (NHB : 2019). The leading states for tomato production in India are U.P. Karnataka, Maharashtra, Haryana, Punjab and Bihar in our country growing of vegetables are 4-8 times more remunerable than cereals and other field crops and also the vegetables cultivation generates more employment in the rural areas. Thus India has to go a long way to accelerate the vegetable production. It plays unique role in vegetable diet and stands next to potato in importance.

The area under tomato cultivation is 4.66 lakh hectares with a production of 82.71 lakh tonnes, contributing 7.95 percent of total area and production (Chadha, 2001). Besides, sufficient vitamins 


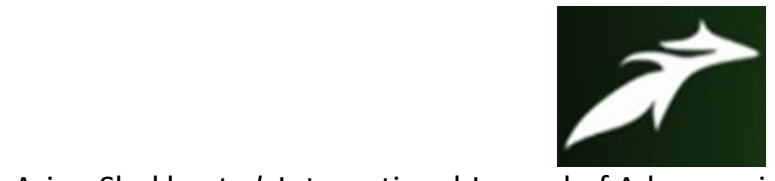

Arjun Shukla et al, International Journal of Advances in Agricultural Science and Technology,

Vol.8 Issue.8, August-2021, pg. 201-209

ISSN: 2348-1358

Impact Factor: 6.057

NAAS Rating: 3.77

like carotene $35 \mathrm{ug}$, thiamine $0.12 \mathrm{mg}$, riboflavin, $0.06 \mathrm{mg}$, niacin $0.4 \mathrm{mg}$ and vitamin C 27 $\mathrm{mg}$ are available /100g fruit, as reported by Gopalan $\boldsymbol{e t}$ al. (2001). It is preferably consumed in skin response to UV-exposure, therefore may represent a first line protection against UV- induced oxidative damage. The green raw tomatoes turn into red when it ripens as the form of lycopene present in tomato gradually changes into transform of lycopene with maturity Xianquan $\boldsymbol{e t}$ al (2005). Lycopene is carotenoid it is the main pigment of tomatoes, conferring to the fruit its red colour. Antioxidants in foods have recently immerged as the bimolecules of almost interest to human health. Dietary antioxidants inactivate reactive oxygen species, reduces oxidative damage lead to improve immuno functions and reduce risk of infectious diseases- increasing intake of dietary oxidant may help to maintain adequate antioxidants status and therefore, the normal physiological functions of living system Kaur and Kapoor (2007)

Sauce and puree are popular tomato products in India. Sauce is used with many foods to enhance the palatability and aesthetic value. The children are very found of tomato sauce. Puree is a form of concentrated juice which acts as convenience food and used in preparation of curries during shortage as well as costliest tomato accessible in the market. Nowadays, many national and multinational companies are involved in preparing sauce and puree with wide dimensions of branding and quality standard too. Tomatoes have a rich flavor, high liquid content, very soft flesh which breaks down easily, and the right composition to thicken into a sauce when they are cooked (without the need of thickeners like roux).

\section{MATERIALS AND METHODS}

Research was carried out at Vegetable Research Farm, Department of horticulture, SHUATS, Prayagraj (U.P.) during winter season of 2020 - 2021, to evaluate the Comparative Studies of Tomato and cherry Tomatoes different varieties under poly house Condition traits of 7 Hybrids, with three replications in Randomized Block Design (RBD). with the spacing of plot length size of $2.25 \mathrm{~m}$ and plot width size of $1 \mathrm{~m}$.. Cost Benefit Ratio of different varieties of tomato, Variable cost and total cost 


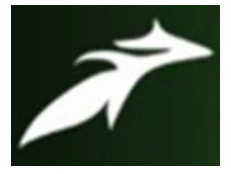

Arjun Shukla et al, International Journal of Advances in Agricultural Science and Technology, Vol.8 Issue.8, August-2021, pg. 201-209

ISSN: 2348-1358

Impact Factor: 6.057

NAAS Rating: 3.77

of cultivation of different varieties, Economics of cherry tomato and tomatos, Yield per hectare $\&$ plant height $(\mathrm{cm})$.

\section{RESULTS AND DISCUSSION}

The present studies on the "Comparative Studies on Tomato and Cherry Tomato Under Polyhouse Condition" was carried out at the field of Department of Horticulture, Naini Agricultural Institute, Sam Higginbottom University of Agriculture, Technology and Sciences, Prayagraj during the year 2020-2021. The observations recorded and results obtained during the period of investigation have been presented in this chapter under the following headings.

The maximum plant height at 30 days after transplanting was recorded by the genotype Sweet Girl i.e. (30.08) followed by Arka Rakshak i.e. (22.08). The maximum plant height at 60 days after transplanting was recorded by the genotype Sweet Girl i.e. (30.08) followed by Arka Rakshak i.e. (22.08).The maximum plant height at 90 days after transplanting was recorded by the genotype Sweet Girl i.e. (30.08) followed by Arka Rakshak i.e. (22.08). These results were in concurrence with the earlier findings of Renuka et al. (2014), Prema et al. (2011a) and Kumar et al. (2014)

Table.1 Plant height (cm) at 30,60 and 90 days after transplanting.

\begin{tabular}{|c|c|c|c|c|}
\hline Treatment No. & Varieties & $\begin{array}{c}\text { Plant height } \mathbf{( c m}) \\
\text { in } \mathbf{3 0} \text { days }\end{array}$ & $\begin{array}{c}\text { Plant height ( } \\
\text { cm) in } \mathbf{6 0} \text { days }\end{array}$ & $\begin{array}{c}\text { Plant height ( } \\
\mathbf{c m} \text { in 90 days }\end{array}$ \\
\hline $\mathrm{T}_{1}$ & Arka rakshak & 22.08 & 67.50 & 87.50 \\
\hline $\mathrm{T}_{2}$ & Arka vikas & 20.50 & 64.58 & 82.50 \\
\hline $\mathrm{T}_{3}$ & Arka abhed & 17.92 & 64.17 & 85.00 \\
\hline $\mathrm{T}_{4}$ & Arka samrat & 18.00 & 60.42 & 77.50 \\
\hline $\mathrm{T}_{5}$ & Sweet boy & 21.08 & 87.92 & 110.00 \\
\hline $\mathrm{T}_{6}$ & Sweet girl & 32.08 & 115.00 & 187.50 \\
\hline $\mathrm{T}_{7}$ & Local & 21.75 & 100.00 & 142.50 \\
\hline & & $\mathbf{S}$ & $\mathbf{S}$ & NS \\
\hline
\end{tabular}




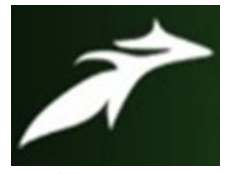

Arjun Shukla et al, International Journal of Advances in Agricultural Science and Technology, Vol.8 Issue.8, August-2021, pg. 201-209

ISSN: 2348-1358

Impact Factor: 6.057

NAAS Rating: 3.77

\begin{tabular}{|c|c|c|c|}
\hline S.Ed ( $\mathbf{\pm})$ & 0.85 & 0.76 & 0.00 \\
\hline C.D. $(\mathbf{P}=\mathbf{0 . 0 5})$ & 2.63 & 2.35 & 0.00 \\
\hline
\end{tabular}

Table. 2 Yield /plant (kg)

\begin{tabular}{|c|c|c|c|c|}
\hline Treatment No. & Varieties & $\begin{array}{c}\text { Yield /plant in } 30 \\
\text { days }\end{array}$ & $\begin{array}{c}\text { Yield/plant in } 60 \\
\text { days }\end{array}$ & $\begin{array}{c}\text { Yield /plant in } 90 \\
\text { days }\end{array}$ \\
\hline T1 & Arka rakshak & 2.25 & 3.22 & 4.11 \\
\hline $\mathrm{T} 2$ & Arka vikas & 2.13 & 3.11 & 3.95 \\
\hline T3 & Arka abhed & 2 & 2.58 & 3 \\
\hline $\mathrm{T} 4$ & Arka samrat & 1.25 & 1.8 & 2.5 \\
\hline T5 & Sweet boy & 1.18 & 2.2 & 2.75 \\
\hline T6 & Sweet girl & 1.5 & 1.95 & 2.4 \\
\hline T7 & Local & 1.17 & 1.85 & 2.2 \\
\hline & & $\mathbf{S}$ & $\mathbf{S}$ & $\mathbf{S}$ \\
\hline & & 0.04 & 0.05 & 0.21 \\
\hline & & 0.08 & 0.11 & 0.46 \\
\hline
\end{tabular}

The Maximum yield at 30 days after transplanting was found to be the genotypes arka rakshak i.e (2.25) followed by arka vikas i.e (2.0).The Maximum yield at 60 days after transplanting was found to be the genotypes arka rakshak i.e (2.25) followed by arka vikas i.e (2.0)The Maximum yield at 90 days after transplanting was found to be the genotypes arka rakshak i.e (2.25) followed by arka vikas i.e (2.0)Thus, the present result correlates with the outcome of , Kumar et al. (2014), Renuka et al. (2014). 


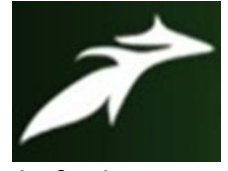

Arjun Shukla et al, International Journal of Advances in Agricultural Science and Technology,

Vol.8 Issue.8, August-2021, pg. 201-209

ISSN: 2348-1358

Impact Factor: 6.057

NAAS Rating: 3.77

\section{Table.3 Yield per hectare}

\begin{tabular}{|c|c|c|}
\hline Treatment No. & Varieties & Yield/hectare (quintal) \\
\hline $\mathrm{T}_{1}$ & Arka rakshak & 887.01 \\
\hline $\mathrm{T}_{2}$ & Arka vikas & 850.90 \\
\hline$T_{3}$ & Arka abhed & 701.83 \\
\hline $\mathrm{T}_{4}$ & Arka samrat & 513.87 \\
\hline$T_{5}$ & Sweet boy & 567.58 \\
\hline $\mathrm{T}_{6}$ & Sweet girl & 541.65 \\
\hline $\mathrm{T}_{7}$ & Local & 483.32 \\
\hline \multicolumn{2}{|c|}{ F-test } & $\mathbf{S}$ \\
\hline \multicolumn{2}{|c|}{ S.Ed ( \pm ) } & 5.00 \\
\hline \multicolumn{2}{|c|}{ C.D. $(P=0.05)$} & 10.89 \\
\hline
\end{tabular}

Among the seven varieties of the study, the genotype arka rakshak (624.9) registered the highest yield hectare-1 followed by arka vikas (555.5). These results were agreement with the reports of Renuka et al. (2014) and Ramya et al. (2016) in cherry tomato.

Table. 4 Economics of cherry tomato and tomatoes

\begin{tabular}{|c|c|c|c|c|c|c|}
\hline Sl. No. & Particulars & Quantity & Unit & Unit Rate & Amount (INR) \\
(INR) & & & 500 \\
\hline A. & Land preparation & \multicolumn{3}{|c|}{ Hours } & & \\
\hline 1 & $\begin{array}{c}\text { Ploughing with mould } \\
\text { board }\end{array}$ & 3 & Hours & 500 & 1,500 \\
\hline 2 & Disc harrowing & 3 & Hours & 300 & 600 \\
\hline
\end{tabular}




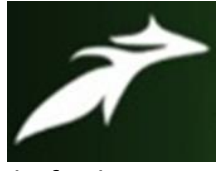

Arjun Shukla et al, International Journal of Advances in Agricultural Science and Technology,

Vol.8 Issue.8, August-2021, pg. 201-209

ISSN: 2348-1358

Impact Factor: 6.057

NAAS Rating: 3.77

\begin{tabular}{|c|c|c|c|c|c|}
\hline 4 & Man days for layout & 8 & Man days & 250 & 2,000 \\
\hline B. & $\begin{array}{c}\text { Fertilizer, Manures } \\
\text { and seed }\end{array}$ & & & & \\
\hline 1 & FYM (Recommended) & 10 & Ton & 600 & 6,000 \\
\hline 2 & Urea $\left(100 \mathrm{~kg} \mathrm{~N} \mathrm{ha}^{-1}\right)$ & 250 & $\mathrm{Kg}$ & 6 & 1,500 \\
\hline 3 & $\mathrm{SSP}\left(50 \mathrm{~kg} \mathrm{P}_{2} \mathrm{O}_{5} \mathrm{ha}^{-1}\right)$ & 315 & $\mathrm{Kg}$ & 10 & 6,000 \\
\hline 4 & $\operatorname{MOP}\left(50 \mathrm{~kg} \mathrm{~K}_{2} \mathrm{O} \mathrm{ha}^{-1}\right)$ & 80 & $\mathrm{Kg}$ & 10 & 800 \\
\hline 5 & $\begin{array}{c}\text { Mandays for fertilizer } \\
\text { application }\end{array}$ & 20 & Mandays & 250 & 5,000 \\
\hline C. & Other material & & & & \\
\hline 1 & Wire & 20 & $\mathrm{Kg}$ & 35 & 700 \\
\hline 2 & Jute rope (Sutli) & 20 & $\mathrm{Kg}$ & 25 & 500 \\
\hline 3 & Bamboo sticks & 700 & Nos. & 6 & 4,200 \\
\hline
\end{tabular}

\begin{tabular}{|c|c|c|c|c|c|}
\hline Sl. No. & Particulars & Quantity & Unit & $\begin{array}{c}\text { Unit Rate } \\
\text { (INR) }\end{array}$ & Amount (INR) \\
\hline D. & Irrigation & & & & \\
\hline 1 & $\begin{array}{l}\text { Tube well charges ( } 2 \\
\text { hrs. per irrigation) }\end{array}$ & 8 & Hours & 400 & 3,200 \\
\hline 2 & $\begin{array}{c}2 \text { Man days per } \\
\text { irrigation }\end{array}$ & 10 & Man days & 250 & 2,500 \\
\hline E. & $\begin{array}{c}\text { Intercultural } \\
\text { operations }\end{array}$ & & & & \\
\hline 1 & $\begin{array}{c}\text { Weeding and hoeing (2 } \\
\text { Nos.) }\end{array}$ & 10 & Man days & 250 & 2,500 \\
\hline 2 & $\begin{array}{c}\text { Insecticides and } \\
\text { Pesticides }\end{array}$ & 5 & Litre & 250 & 1,250 \\
\hline 2 & Spraying of chemicals & 5 & Man days & 300 & 1500 \\
\hline
\end{tabular}




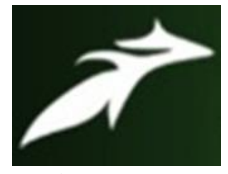

Arjun Shukla et al, International Journal of Advances in Agricultural Science and Technology, Vol.8 Issue.8, August-2021, pg. 201-209

ISSN: 2348-1358

Impact Factor: 6.057

NAAS Rating: 3.77

\begin{tabular}{|c|c|c|c|c|c|}
\hline F. & Harvesting & & & & \\
\hline 1 & $\begin{array}{c}10 \text { Man days per day } \\
\text { for 4 days }\end{array}$ & 40 & Man days & 300 & 12000 \\
\hline 2 & Transportation charges & & L. S. & 3,000 \\
\hline G. & Overhead cost & & Months & 3000 & 1000 \\
\hline 1 & Supervision charges & 4 & Months & & 12,000 \\
\hline Total cost of cultivation (INR ha & & & \\
\hline
\end{tabular}

The economics of the tomatos and cherry tomatos of all the variety was calculated by summed cost of all agronomical practices, protection measure, land rent etc. including labour and farm machinery. The total cost of cultivation is (INR 71,100) and the variable cost of cultivation varies between (INR 78,800 to INR $80,100)$. The total yield of particular varities is multiplied by market price of tomatos and cherry tomatos at a time. The total cost of cultivation is subtracted from total income, all the middleman margin and market charge was substracted from total income for determining the net return.

\section{Gross return hectare ${ }^{-1}$}

The maximum gross return hectare ${ }^{-1}$ was obtained by (Arka rakshak) i.e. INR 3,54,804 and followed by (Arka vikas)i.e. INR 3,40,360 and the minimum gross return hectare ${ }^{-1}$ was obtained by (local cherry tomatoes)i.e. NR 1,93,328.

\section{Net return per hectare ${ }^{-1}$}

The maximum net income per hectare was obtained by (Arka rakshak) i.e. INR 2,79,554 and followed by the (Arka vikas) i.e. INR 2,65,110 and the minimum net return per hectare was obtained by (local cherry tomatoes)i.e. INR 1,18,078. 


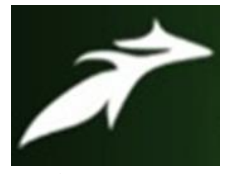

Arjun Shukla et al, International Journal of Advances in Agricultural Science and Technology,

Vol.8 Issue.8, August-2021, pg. 201-209

ISSN: 2348-1358

Impact Factor: 6.057

NAAS Rating: 3.77

\section{Cost Benefit Ratio}

Among the different varieties (Arka rakshak) has the highest cost benefit ratio (3.72) followed by (Arka Vikas) i.e. (3.52) and the minimum cost benefit ratio was showed by (local) i.e. (1.57).

Table. 5 Variable cost and total cost of cultivation of different varieties.

\begin{tabular}{|c|c|c|c|c|c|c|}
\hline \multirow[b]{2}{*}{$\begin{array}{c}\text { Treatment } \\
\text { Symbol }\end{array}$} & \multirow[b]{2}{*}{ Varieties } & \multicolumn{3}{|c|}{ Seed cost } & \multirow[b]{2}{*}{$\begin{array}{l}\text { Fixed cost } \\
\text { INR/ha }\end{array}$} & \multirow[b]{2}{*}{$\begin{array}{c}\text { Total cost of } \\
\text { cultivation }\end{array}$} \\
\hline & & $\begin{array}{l}\text { Qty. } \\
\text { Kg/ha }\end{array}$ & $\begin{array}{l}\text { Rate } \\
\text { INR/ha }\end{array}$ & $\begin{array}{c}\text { Amount } \\
\text { INR }\end{array}$ & & \\
\hline$\overline{T_{1}}$ & Arka rakshak & 0.15 & 20,000 & 3,000 & 72,250 & 75,250 \\
\hline $\mathrm{T}_{2}$ & Arka vikas & 0.15 & 20,000 & 3,000 & 72,250 & 75,250 \\
\hline $\mathrm{T}_{3}$ & Arka abhed & 0.15 & 20,000 & 3,000 & 72,250 & 75,250 \\
\hline $\mathrm{T}_{4}$ & Arka samrat & 0.15 & 20,000 & 3,000 & 72,250 & 75,250 \\
\hline$T_{5}$ & Sweet girl & 0.15 & 20,000 & 3,000 & 72,250 & 75,250 \\
\hline $\mathrm{T}_{6}$ & Sweet boy & 0.15 & 20,000 & 3,000 & 72,250 & 75,250 \\
\hline $\mathrm{T}_{7}$ & Local & 0.15 & 20,000 & 3,000 & 72,250 & 75,250 \\
\hline
\end{tabular}

Table. 6 Cost Benefit Ratio of different varieties of tomato and cherry tomatos

\begin{tabular}{|c|c|c|c|c|c|c|c|}
\hline Treatment & Hybrids & $\begin{array}{c}\text { Total cost of } \\
\text { cultivation/ha }\end{array}$ & Yield q/ha & $\begin{array}{c}\text { Selling Rate } \\
\text { INR/q }\end{array}$ & $\begin{array}{c}\text { Gross } \\
\text { return @ } \\
\text { INR/ha }\end{array}$ & $\begin{array}{c}\text { Net Return } \\
\text { INR/ha }\end{array}$ & $\begin{array}{c}\text { Benefit Cost } \\
\text { Ratio }\end{array}$ \\
\hline$T_{1}$ & Arka rakshak & $\mathbf{7 5 , 2 5 0}$ & 887.01 & 400 & 354804 & 279,554 & 3.72 \\
\hline$T_{2}$ & Arka vikas & $\mathbf{7 5 , 2 5 0}$ & 850.90 & 400 & 340360 & 265,110 & 3.52 \\
\hline$T_{3}$ & Arka abhed & $\mathbf{7 5 , 2 5 0}$ & 701.83 & 400 & 280732 & 205,482 & 2.73 \\
\hline $\mathrm{T}_{4}$ & Arka samrat & $\mathbf{7 5 , 2 5 0}$ & 513.87 & 400 & 205548 & 130,298 & 1.73 \\
\hline
\end{tabular}




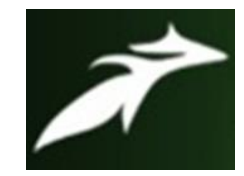

Arjun Shukla et al, International Journal of Advances in Agricultural Science and Technology, Vol.8 Issue.8, August-2021, pg. 201-209

ISSN: 2348-1358

Impact Factor: 6.057

NAAS Rating: $\mathbf{3 . 7 7}$

\begin{tabular}{|c|c|c|c|c|c|c|c|}
\hline$T_{5}$ & Sweet girl & $\mathbf{7 5 , 2 5 0}$ & 567.58 & 400 & 227032 & 151,782 & 2.02 \\
\hline $\mathrm{T}_{6}$ & Sweet boy & $\mathbf{7 5 , 2 5 0}$ & 541.65 & 400 & 216660 & 141,410 & 1.88 \\
\hline $\mathrm{T}_{7}$ & Local & $\mathbf{7 5 , 2 5 0}$ & 483.32 & 400 & 193328 & 118,078 & 1.57 \\
\hline
\end{tabular}

\section{REFERENCES}

[1]. Anand, M. 2007. Studies on development of $F_{1}$ hybrids for high yield and quality in tomato. (Lycopersicon esculentum Mill.). Ph.D. Thesis, Tamil Nadu Agricultural University, Coimbatore.

[2]. Anandgowda, N. 1997. Variability and gene action-studies for characteristics related to processing in tomato (Lycopersicon esculentum Mill.). M.Sc. Thesis, University of Agricultural Sciences, Dharwad.

[3]. Anitha, P., R.R. Sharma, R.N. Tiwari and A.K. Surja. 2007. Correlation and path analysis for some horticultural traits in tomato. Indian J. Hort., 64 (1): 90-93.

[4]. Bhusana, H.O., R.S. Kulkarni, D. Basavarajaiah, B.H. Helaswamy and G.K. Halesh. 2001. Correlation and path analysis for fruit quality traits on fruit yield in tomato (Lycopersicon esculentum Mill.). Crop Res., 22 (1): 107-109.

[5]. Biswas, V.R., R.P. Bhatt and N. Kumar. 2011. Gene action in tomato (Lycopersicon esculentum Mill.) under open and protected environments. Veg. Sci., 38 (2): 206-208.

[6]. Boches, P., B. Peterschmidt and J.R. Myers. 2011. Evaluation of a subset of the Solanum lycopersicum var. cerasiforme core collection for horticultural quality and fruit phenolic content. HortScience, 46 (11): 1450-1455.Burgis, D.S. and G.J. Wilfret. 1979. Cherry type tomatoes in Florida: an evaluation of four varieties. Proc. Fla. State Hort. Soc., 92: 134-136.

[7]. Ceballos-Aguirre, N. and F.A. Vallejo-Cabrera. 2012. Evaluating the fruit production and quality of cherry tomato (Solanum lycopersicum var. cerasiforme). Rev. Fac. Nal. Agr. Medellin., 65 (2): 6593-6604

[8]. Crop production techniques of horticultural crops. 2013. In: Directorate of Horticulture and Plantation Crops, Chennai and Tamil Nadu Agricultural University, Coimbatore, pp. 54-56.

[9]. Dorairaj, A. 1981. Quality evaluation of tomato (Lycopersicon esculentum Mill.) cultivars and hybrids for processing. M.Sc. Thesis, Tamil Nadu Agricultural University, Coimbatore.

[10].Dundi, K.B. and B.B. Mandalageri. 1991. Heterosis for shelf-life and its components in tomato (Lycopersicon esculentum Mill.). South Indian Hort., 39: 353-355.

[11].Gomathi, S.P. 2008. Development of semi determinate $F_{1}$ hybrids in tomato (Solanum lycopersicum Mill.) with combined resistance to viral diseases and nematodes. M.Sc. Thesis, Tamil Nadu Agricultural University, Coimbatore.

[12].Haydar, A., M.A. Mandal, M.B. Ahmed, M.M. Hannan, R. Karim, M.A. Razvy, U.K. Roy and M. Salahin. 2007. Studies on genetic variability and interrelationship among the different traits in tomato (Lycopersicon esculentum Mill.). Middle-East J. Sci. Res., 2 (3-4): 139-142. 